\title{
Development of Al-Mn-Mg 3004 alloy for applications at elevated temperature via dispersoid strengthening
}

\author{
K. Liu*, X. -G. Chen \\ Department of Applied Science, University of Quebec at Chicoutimi, \\ Saguenay, QC, Canada, G7H 2B1 \\ *Corresponding author: kun.liu@uqac.ca; Tel.: 1-4185455011 ext. 7112; Fax. :1-4185455012
}

\begin{abstract}
In this study, the potential applications of Al-Mn-Mg 3004 alloy at elevated temperature have been evaluated through the systematic study of the precipitation behavior of $\alpha-\mathrm{Al}(\mathrm{MnFe}) \mathrm{Si}$ dispersoids and their effect on material properties during precipitation treatment and long-term thermal holding. The results demonstrate a significant dispersion strengthening effect caused by the precipitation of fine uniformly distributed dispersoids during precipitation treatment. The peak compression yield strength (YS) at $300^{\circ} \mathrm{C}$ of the experimental 3004 alloy can reach as high as $78 \mathrm{MPa}$ due to a large volume fraction ( 2.95 vol. \%) of $\alpha-\mathrm{Al}(\mathrm{MnFe}) \mathrm{Si}$ dispersoids. The dispersoids are found to be thermally stable at $300^{\circ} \mathrm{C}$ for up to $1000 \mathrm{~h}$ of holding, leading to consistently high mechanical performance and creep resistance. The superior and stable YS and creep resistance at $300^{\circ} \mathrm{C}$ enables the 3004 alloy to be applied to weight-sensitive applications at elevated temperatures.
\end{abstract}

Keywords: Al-Mn-Mg 3004 alloy; Precipitation treatment; Dispersoid strengthening; Thermal stability; Creep resistance; Elevated temperature applications.

\section{Introduction}

Currently, the demand for aluminum alloys that offer excellent performance at elevated temperatures $\left(250 \sim 350{ }^{\circ} \mathrm{C}\right)$ is increasing, driven by the automotive and aerospace industries requiring higher strength, lower cost and lighter structural components. However, the strength of traditional precipitation strengthening alloys, such as $2 \mathrm{xxx}, 6 \mathrm{xxx}$ and $7 \mathrm{xxx}$ alloys, can be seriously deteriorated due to the rapid coarsening of precipitates at elevated temperature (i.e., the overaging effect) [1,2]. Conversely, dispersoid strengthening is reported to be an important hardening mechanism at elevated temperature in aluminum alloys [3-8]. Therefore, developing low cost and thermally stable aluminum alloys with dispersoid precipitation that function well at elevated temperature is particularly attractive for these industries. 
AA3xxx alloys are one of the most widely used commercial wrought aluminum alloys in architecture and the packaging industry due to its excellent formability and corrosion resistance [9]. Different from heat treatable aluminum alloys, such as $2 \mathrm{xxx}$, $6 \mathrm{xxx}$ and $7 \mathrm{xxx}$ alloys, in which fine nano-scale precipitates form during heat treatment to increase strength, AA3xxx alloys are generally strengthened by work hardening and therefore classified as non-heat treatable alloys. Recently, several studies found that a reasonable amount of dispersoids can precipitate during heat treatment in 3xxx alloys [3, $5,10,11]$. Therefore, increasing interests on $3 \times x x$ alloys for applications at elevated temperature have been developed.

In AA3xxx alloys, $\mathrm{Mn}$ is a primary alloying element, and most will be dissolved in the aluminum matrix to form a supersaturated solid solution during solidification [3, 4, 11]. During homogenization, the dispersoids form via the decomposition of the supersaturated solid solution. Many investigations have been performed on the precipitation of dispersoids in 3xxx alloys [3-5, 9-14]. The type of dispersoids varies with the alloy composition and homogenization treatment. It was reported that $\alpha-\mathrm{Al}(\mathrm{MnFe}) \mathrm{Si}$ prefers to precipitate with a high $\mathrm{Si}$ level, while $\mathrm{Al}_{6}(\mathrm{MnFe})$ is stable dispersoids with lower $\mathrm{Si}$ content $[3,5,10]$. In these two types of dispersoids, Fe and Mn can substitute for each other, but the structure of $\alpha-\mathrm{Al}(\mathrm{MnFe}) \mathrm{Si}$ tends to transform from simple cubic to body centered cubic with increasing $\mathrm{Fe} / \mathrm{Mn}$ ratio $[3,11]$. However, $\alpha-\mathrm{Al}(\mathrm{MnFe}) \mathrm{Si}$ dispersoids dissolve slowly, and $\mathrm{Al}_{6}(\mathrm{MnFe})$ dispersoids precipitate with increasing homogenization temperature and holding time [3,5]. The precipitation behavior of dispersoids have been studied during the heat treatment at high temperatures $\left(450 \sim 600^{\circ} \mathrm{C}\right)$ [4]. However, limited open literature focusing on the formation of dispersoids at lower temperatures $\left(300 \sim 400^{\circ} \mathrm{C}\right)$ can be reached.

Recently, dispersoids have been reported to have a noticeable effect on tensile strength at room temperature (RT) in 3003 alloys [5, 11, 13]. Due to the high precipitation temperature of $\mathrm{Al}_{6}(\mathrm{MnFe})$ at $\sim 600^{\circ} \mathrm{C}[5,10], \alpha-\mathrm{Al}(\mathrm{MnFe}) \mathrm{Si}$ is often referred to as the dominant dispersoids in 3xxx alloys in the literature. In 3003 alloys, $\alpha-\mathrm{Al}(\mathrm{MnFe}) \mathrm{Si}$ is reported to be partially coherent with a matrix and therefore improves mechanical properties $[5,10]$. However, the improvement in mechanical properties at RT is limited due to a low volume fraction of dispersoids. In the study by $\mathrm{Li}$ et al. [3], the volume fraction of dispersoids was reported to be only 0.77 vol.\%, resulting in a limited contribution to mechanical properties. On the other hand, the strengthening mechanisms involved at elevated temperature are more complex than at RT. However, limited information about the effect of dispersoids on mechanical properties at elevated temperature has been reported.

Additionally, thermal stability and creep resistance are two important considerations during the selection of high temperature alloys [15-18]. In the study by Lai et al. [19], it was reported that $\mathrm{Al}_{3} \mathrm{Sc}$ dispersoids were thermally stable at up to $250^{\circ} \mathrm{C}$, while $\mathrm{Al}_{3}(\mathrm{ScZr})$ could be stable at $300^{\circ} \mathrm{C}$ during prolonged exposure at service temperatures in $\mathrm{Al}-\mathrm{B}_{4} \mathrm{C}$ 
composites. It was also found that creep resistance increased due to the introduction of dispersoids in Al-matrix composites [20, 21]. However, limited information is available in the literature for the thermal stability and creep resistance of 3xxx alloys at elevated temperature.

The goal of this study is to assess the potential of $3 \mathrm{xxx}$ alloys for applications at elevated temperature. We have systematically studied the precipitation behavior of dispersoids and their effect on material properties, such as electrical conductivity (EC), Vickers microhardness and yield strength (YS) at both ambient and elevated temperature $\left(300^{\circ} \mathrm{C}\right)$. Moreover, the long-term thermal stability of dispersoids at $300^{\circ} \mathrm{C}$ for up to 1000 hours has been evaluated. The effect of dispersoids on creep resistance at elevated temperature has also been reported.

\section{Experimental}

\subsection{Alloy preparation}

Experimental 3004 alloy was prepared with commercially pure $\mathrm{Al}(99.7 \%)$ and pure $\mathrm{Mg}$ (99.9\%), Al-25\% Fe, Al-50\% Si and Al-25\% Mn master alloys. The chemical composition of the experimental 3004 alloy analyzed using optical emission spectrometer (OES) is shown in Table 1.

Table 1 Composition of experimental and AA standard 3004 alloy

\begin{tabular}{ccccccc}
\hline Elements (wt. \%) & $\mathrm{Mn}$ & $\mathrm{Mg}$ & $\mathrm{Fe}$ & $\mathrm{Si}$ & $\mathrm{Cu}$ & $\mathrm{Al}$ \\
\hline AA 3004 [22] & $1.0-1.5$ & $0.8-1.3$ & 0.7 (Max.) & 0.3 (Max.) & 0.25 (Max.) & Bal. \\
\hline Experimental & 1.2 & 1.1 & 0.6 & 0.25 & 0.01 & Bal. \\
\hline
\end{tabular}

In each test, approximately $3 \mathrm{~kg}$ of material was prepared in a clay-graphite crucible using an electric resistance furnace. The temperature of the melt was maintained at $\sim 750^{\circ} \mathrm{C}$ for $30 \mathrm{~min}$. The melt was degassed for $15 \mathrm{~min}$ and then poured into a permanent mold preheated at $250^{\circ} \mathrm{C}$. The dimension of cast ingots was $30 \mathrm{~mm} \times 40 \mathrm{~mm} \times 80 \mathrm{~mm}$.

\subsection{Heat treatment}

To evaluate the precipitation behavior of dispersoids during the precipitation treatment, which is referred as "precipitation treatment" in the present study to distinguish this process from the "aging treatment" of heat-treatable alloys, cast ingots were treated at $300 \sim 425^{\circ} \mathrm{C}$ for up to 72 hours. After precipitation treatment, the ingots were directly quenched into water at RT. The parameters of the heat treatment are listed in Table 2.

A prolonged thermal holding at $300{ }^{\circ} \mathrm{C}$ up to 1000 hours was performed to examine the thermal stability of the material's mechanical properties at elevated temperature. Prior to the thermal holding process, samples were heat-treated with the peak precipitation treatment. The parameters of the thermal holding process and the peak precipitation 
treatment are shown in Table 2. The parameters of the peak precipitation treatments are based on the results in Fig. 6.

Table 2 Parameters of heat treatments used in this study

\begin{tabular}{cccccr}
\hline Precipitation treatment & \multicolumn{3}{c}{ Thermal holding treatment } \\
\hline \multirow{2}{*}{$\mathrm{T}\left({ }^{\circ} \mathrm{C}\right)$} & Time $(\mathrm{h})$ & \multicolumn{2}{c}{$\begin{array}{c}\text { Peak precipitation } \\
\text { treatment }\end{array}$} & Thermal Holding \\
\cline { 3 - 6 } & & $\mathrm{T}\left({ }^{\circ} \mathrm{C}\right)$ & Time $(\mathrm{h})$ & $\mathrm{T}\left({ }^{\circ} \mathrm{C}\right)$ & Time $(\mathrm{h})$ \\
\hline 300 & & & 300 & up to 1000 \\
350 & up to 72 & $375^{\circ} \mathrm{C}$ & $48 \mathrm{~h}$ & & \\
375 & & & & & \\
425 & & & &
\end{tabular}

\subsection{Evolution of alloy properties}

The precipitation behavior of dispersoids during precipitation treatment and thermal holding were evaluated by EC, Vickers microhardness and YS. EC was measured using a Sigmascope SMP10 electrical conductivity unit at RT, and the average value of 5 measurements was recorded for each sample. Microhardness tests were performed on a NG-1000 CCD microhardness test machine with a load of $200 \mathrm{~g}$ and a dwell time of $20 \mathrm{~s}$ on polished samples. The locations of indentation were on the Al matrix to determine the influence of dispersoids precipitation on hardness. The average value of 20 measurements was recorded for each sample. The mechanical property (YS) was obtained from compression tests performed on a Gleeble 3800 machine. Cylindrical specimens with a length/diameter ratio of 1.5 (i.e., $15 \mathrm{~mm}$ in length and $10 \mathrm{~mm}$ in diameter) were machined and tested at both RT and an elevated temperature $\left(300^{\circ} \mathrm{C}\right)$. The total deformation of the specimens was set to 0.2 , and the strain rate was fixed at $10^{-3} \mathrm{~s}^{-1}$. For the compression test at $300^{\circ} \mathrm{C}$, the specimen was heated to $300^{\circ} \mathrm{C}$ with a heating rate of $2^{\circ} \mathrm{C} / \mathrm{s}$ and held for 3 minutes to stabilize. An average value of YS was obtained from 3 tests.

In addition, creep tests were performed at $300^{\circ} \mathrm{C}$ for 100 hours on some selected conditions. Creep specimens were the same size as the Gleeble samples. Creep tests were conducted under compression with a constant load of $45 \mathrm{MPa}$. For each condition, 3 tests were repeated to confirm the reliability of the results.

\subsection{Microstructure observation}

The microstructural features including the intermetallics, dispersoids and grain structures for different conditions were observed by optical and electron microscopes. To reveal the dispersoids clearly, the polished samples were etched in $0.5 \% \mathrm{HF}$ for 30 seconds. A differential scanning calorimeter (DSC, Perkin Elmer DSC 8000) was used to confirm the formation of intermetallics during solidification as well as the precipitation of 
dispersoids during heat treatment. The heating rate was set to $10^{\circ} \mathrm{C} / \mathrm{min}$. A scanning electron microscope (SEM, JSM-6480LV) equipped with an energy dispersive x-ray spectrometer (EDS) and electron backscatter diffraction (EBSD) was used to examine the intermetallics and grain structure of the alloy under different conditions. A transmission electron microscope (TEM, JEM-2100) operated at $200 \mathrm{kV}$ was used to observe the distribution of dispersoids. The thickness of the TEM sample was measured with electron energy loss spectroscopy (EELS). The size and number density of dispersoids were measured using Clemex PE 4.0 image analysis software with the TEM images. In this study, the volume fraction of particle free zone (PFZ) was converted from the area fraction of PFZ measured in image analysis from optical images according to the Delesse's principle [23, 24] while the volume fraction of dispersoids was calculated according to the model introduced in the literature [3] and shown in Eq. (1):

$$
V_{\mathrm{v}}=A_{\mathrm{A}} \frac{\overline{\mathrm{K}} \overline{\mathrm{K}} \mathrm{D}+\mathrm{t}}{\overline{\mathrm{D}}}\left(1-A_{\mathrm{PFZ}}\right)
$$

where $\bar{D}$ is the average equivalent diameter of dispersoids, which is calculated according to the literature [3]; $\mathrm{t}$ is the TEM foil thickness; $A_{\mathrm{A}}$ is the area percentage of dispersoids from TEM observation; $A_{\mathrm{PFZ}}$ is the area percentage of the particle free zone (PFZ) from OM measurements; and $\bar{K}$ is the average shape factor of dispersoids. In this study, $\bar{K}$ is modified to equal 1 at $300^{\circ} \mathrm{C}$ and $350^{\circ} \mathrm{C}$, and 0.45 at $375^{\circ} \mathrm{C}$ and $425^{\circ} \mathrm{C}$ according to the shape of dispersoids in TEM observations [3].

\section{Results and Discussion}

3.1 Microstructures in as-cast and heat-treated conditions

Fig. 1 shows the as-cast microstructure in the experimental 3004 alloy. The SEMEDS results in Fig. 1c displays that the as-cast microstructure is composed of a dominant intermetallic phase, a large gray $\mathrm{Al}_{6}(\mathrm{MnFe})$ intermetallic, a minor phase of black $\mathrm{Mg}_{2} \mathrm{Si}$ (Fig. 1a), and a small amount of $\alpha-\mathrm{Al}(\mathrm{MnFe}) \mathrm{Si}$ intermetallic (Fig. 1b), which are consistent with the literature $[25,26]$. Due to the presence of $\mathrm{Si}$, the $\alpha-\mathrm{Al}(\mathrm{MnFe}) \mathrm{Si}$ intermetallic can be clearly distinguished from the large $\mathrm{Al}_{6}(\mathrm{MnFe})$ particles because this phase is brighter than $\mathrm{Al}_{6}(\mathrm{MnFe})$ in the SEM backscattered image (Fig. 1b).

DSC was also used to confirm the as-cast microstructure. Fig. 2 shows the DSC heating curve of the as-cast 3004 alloy; three peaks are present during heating in addition to the $\mathrm{Al}$ main peak. According to the temperature range in the DSC heating curve for each phase [27, 28], the three peaks correspond to the melting temperatures of 505, 590 and $635^{\circ} \mathrm{C}$ for $\mathrm{Mg}_{2} \mathrm{Si}, \alpha-\mathrm{Al}(\mathrm{MnFe}) \mathrm{Si}$ and $\mathrm{Al}_{6}(\mathrm{FeMn})$ intermetallic phases, respectively. 

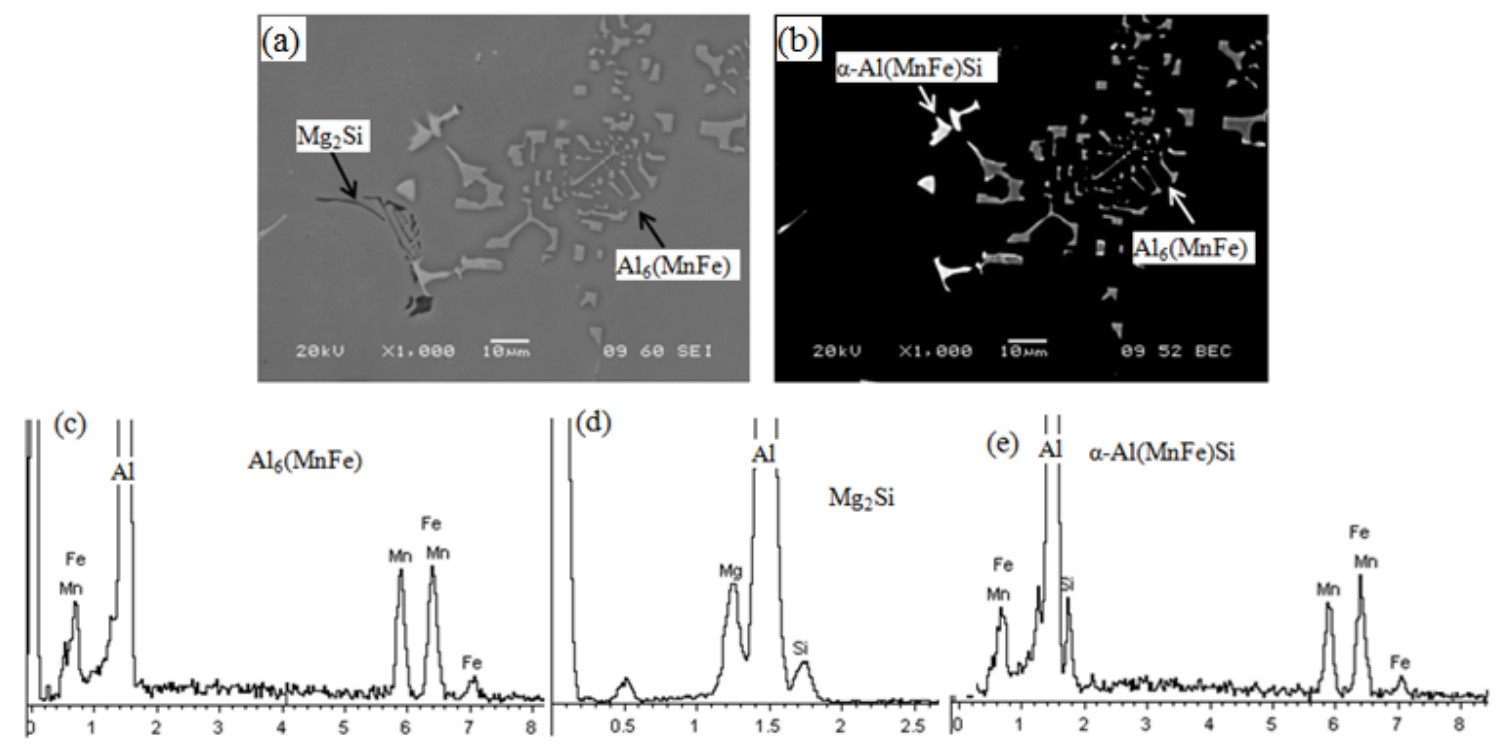

Fig. 1 As-cast microstructures (a-b) and SEM-EDS results (c-e) of the experimental 3004 alloy

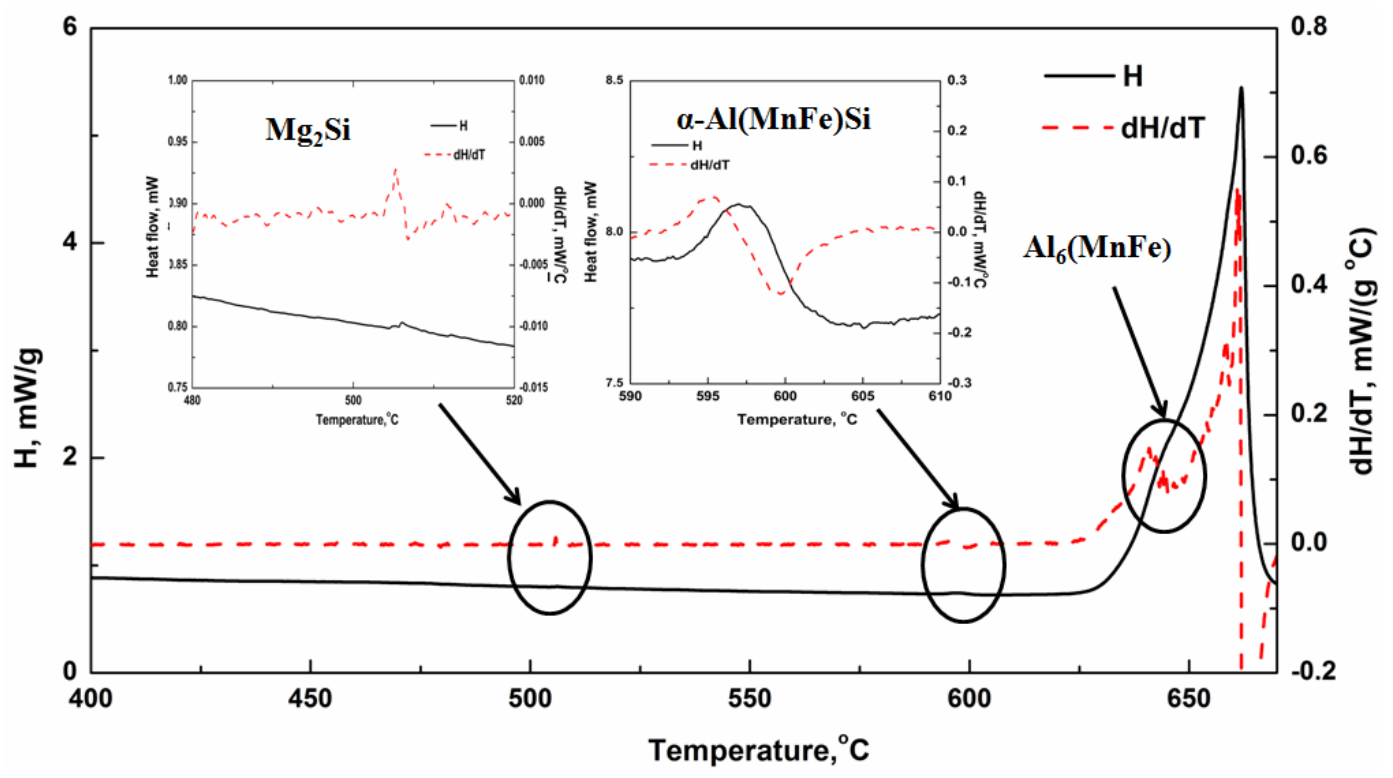

Fig. 2 DSC heating curves of the experimental 3004 alloy

During precipitation treatment, the large $\mathrm{Al}_{6}(\mathrm{MnFe})$ intermetallics begin to fragment, particularly when the alloy was treated at a high temperature $\left(425^{\circ} \mathrm{C}\right)$. As shown in Fig. 3 , it can be found that the $\mathrm{Al}_{6}(\mathrm{MnFe})$ were still Chinese script with large branches after being treated at $300^{\circ} \mathrm{C}$ for $48 \mathrm{~h}$ (Fig. 3a), while the branches fragmented into disconnected parts after being treated at $425^{\circ} \mathrm{C}$ for $48 \mathrm{~h}$ (Fig. 3b). Conversely, only minor changes were 
observed on the $\alpha-\mathrm{Al}(\mathrm{MnFe}) \mathrm{Si}$ and $\mathrm{Mg}_{2} \mathrm{Si}$ intermetallics due to their small size and low volume fractions.
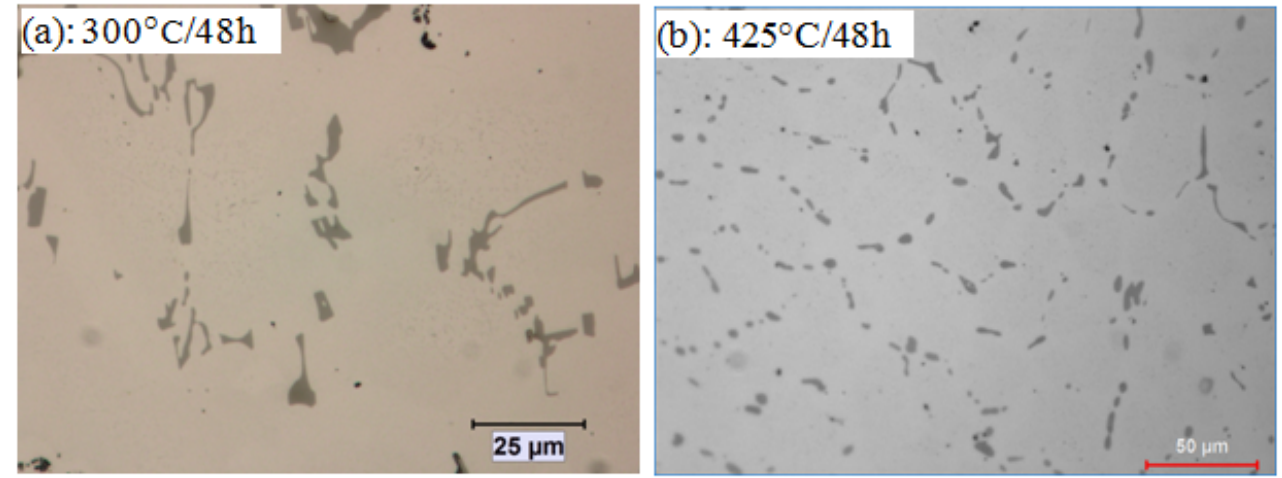

Fig. 3 Evolution of $\mathrm{Al}_{6}(\mathrm{MnFe})$ during precipitation treatment:

(a) $300^{\circ} \mathrm{C}$ for $48 \mathrm{~h}$ and (b) $425^{\circ} \mathrm{C}$ for $48 \mathrm{~h}$

Besides, a high volume of dispersoids formed in the dendrite cells and grains during precipitation treatment. Fig. 4 shows the precipitation of dispersoids in the alloy treated at $375^{\circ} \mathrm{C}$ for $24 \mathrm{~h}$ in the SEM and TEM observations as well as the selected area diffraction pattern (SADP) taken along the zone axes of the [001] Al matrix. As shown in Fig. 4a, the dispersoids are uniformly distributed in the grains. The dispersoids are generally present in two morphologies, cubic and plate-like, as indicated by the arrow in Fig. 4b. Fig. 4c displays the SADP of one single dispersoid along the [211] Al matrix. It can be found that the dispersoids have been well indexed as $\alpha-\mathrm{Al}(\mathrm{MnFe}) \mathrm{Si}$ and shows the orientation as $[21 \overline{1}]_{\mathrm{Al}} / /[0 \overline{1} 1]_{\text {dipsersoids }}$ with the coincidence between planes $(1 \overline{1} 1)_{\mathrm{Al}}$ and (044) dispersoids. Besides, TEM-EDS results shown in Fig. 4d confirm that the dispersoids are composed with $\mathrm{Al}, \mathrm{Mn}, \mathrm{Fe}$ and $\mathrm{Si}$ elements. Finally, the dispersoids with two morphologies (Fig. 4b) are both defined as $\alpha-\mathrm{Al}(\mathrm{MnFe}) \mathrm{Si}$ with a composition of $\mathrm{Al}_{12-20}(\mathrm{FeMn})_{3} \mathrm{Si}_{2}$ according to the SADPs and TEM-EDS results, which is in consistence with the literature [10].

However, few dispersoids are observed surrounding the intermetallic particles (area "A" in Fig. 5a), which is defined as a particle free zone (PFZ). This can be attributed to the depletion of $\mathrm{Mn}$ content near the intermetallics due to the formation of $\mathrm{Al}_{6}(\mathrm{MnFe})$ intermetallic particles in the interdendritic regions. However, some PFZs are also observed in the center of dendrite arms. As shown in area "B" in Fig. 5a and Fig. 5b, the volume fraction of dispersoids is much lower than the peripheral areas of the dendrite arm, which is a result of the low Mn concentration and enriched Mn toward the dendrite boundary due to the segregation of Mn during solidification. 

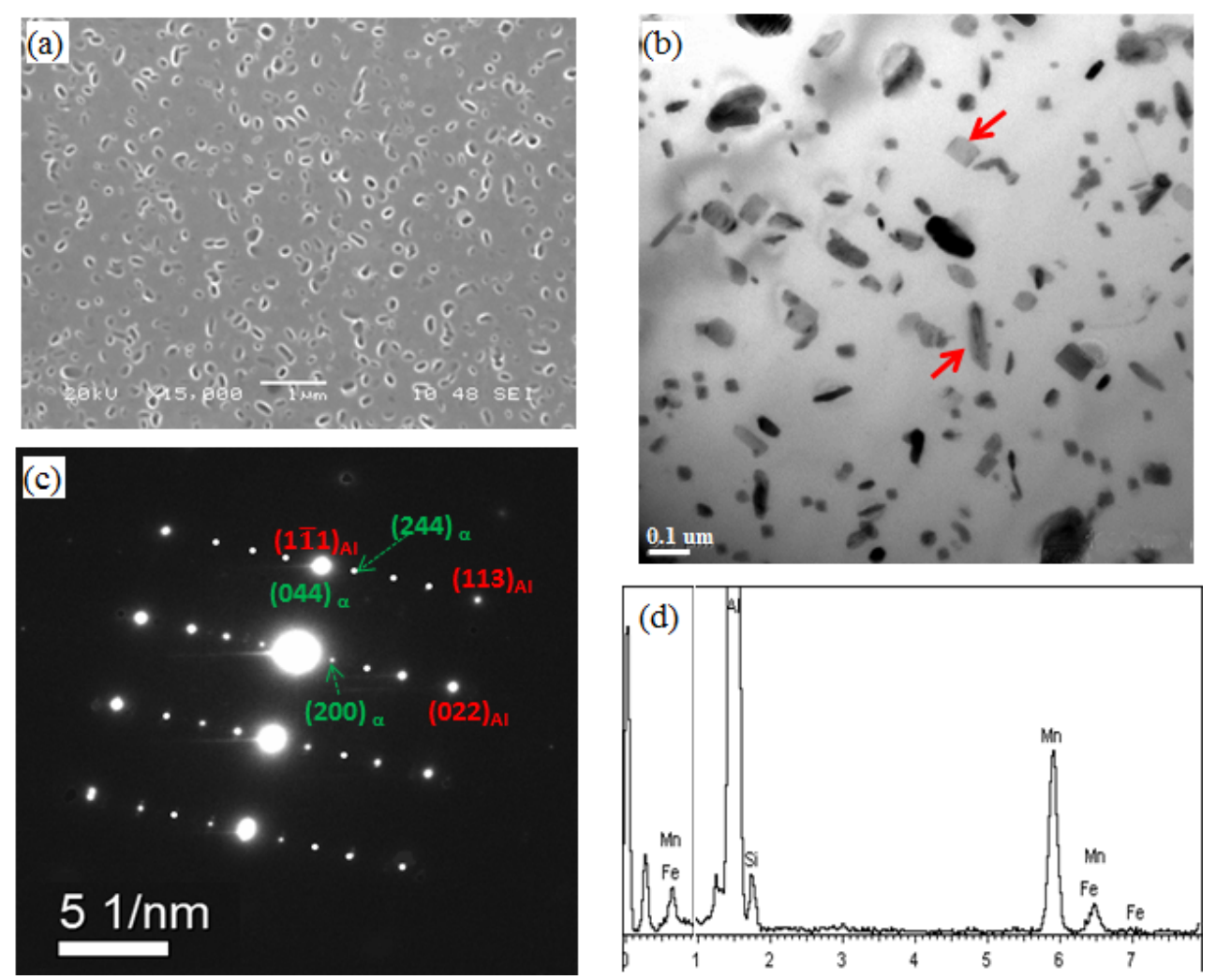

Fig. 4 Type of morphology of dispersoids: (a) SEM and (b)TEM image and SADP along $[21 \overline{1}]_{\mathrm{Al}}$ (c) as well as the TEM-EDS results of dispersoids (d) in the sample treated at $375^{\circ} \mathrm{C}$ for $48 \mathrm{~h}$
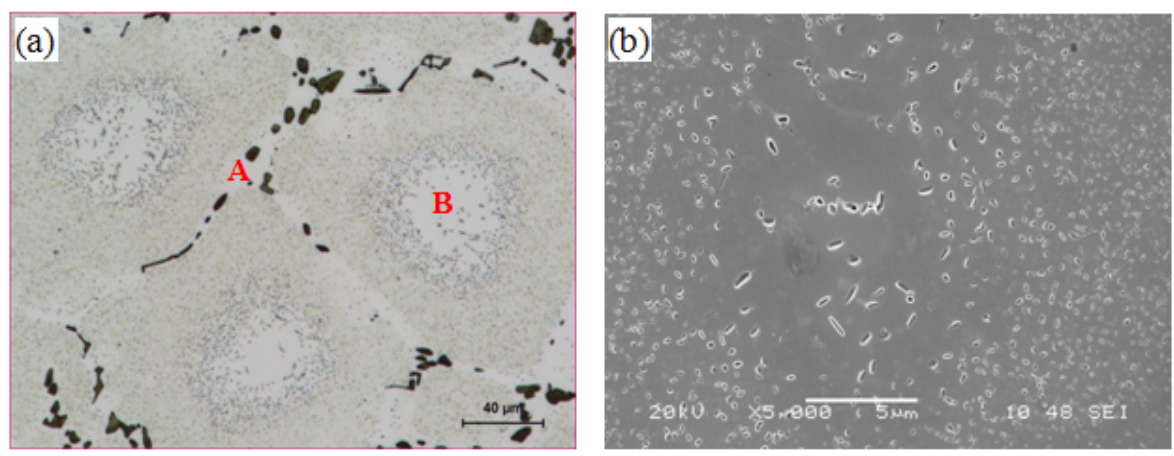

Fig. 5 Formation of PFZ in alloy treated at $425^{\circ} \mathrm{C}$ for $48 \mathrm{~h}$ :

(a) OM and (b) SEM, an enlargement of (a)

\subsection{Evolution of properties during precipitation treatment}

To study the precipitation behavior of dispersoids, precipitation treatments at different temperature and times (Table 2) were performed on the experimental alloy; the evolution of EC and microhardness are shown in Fig. 6. 

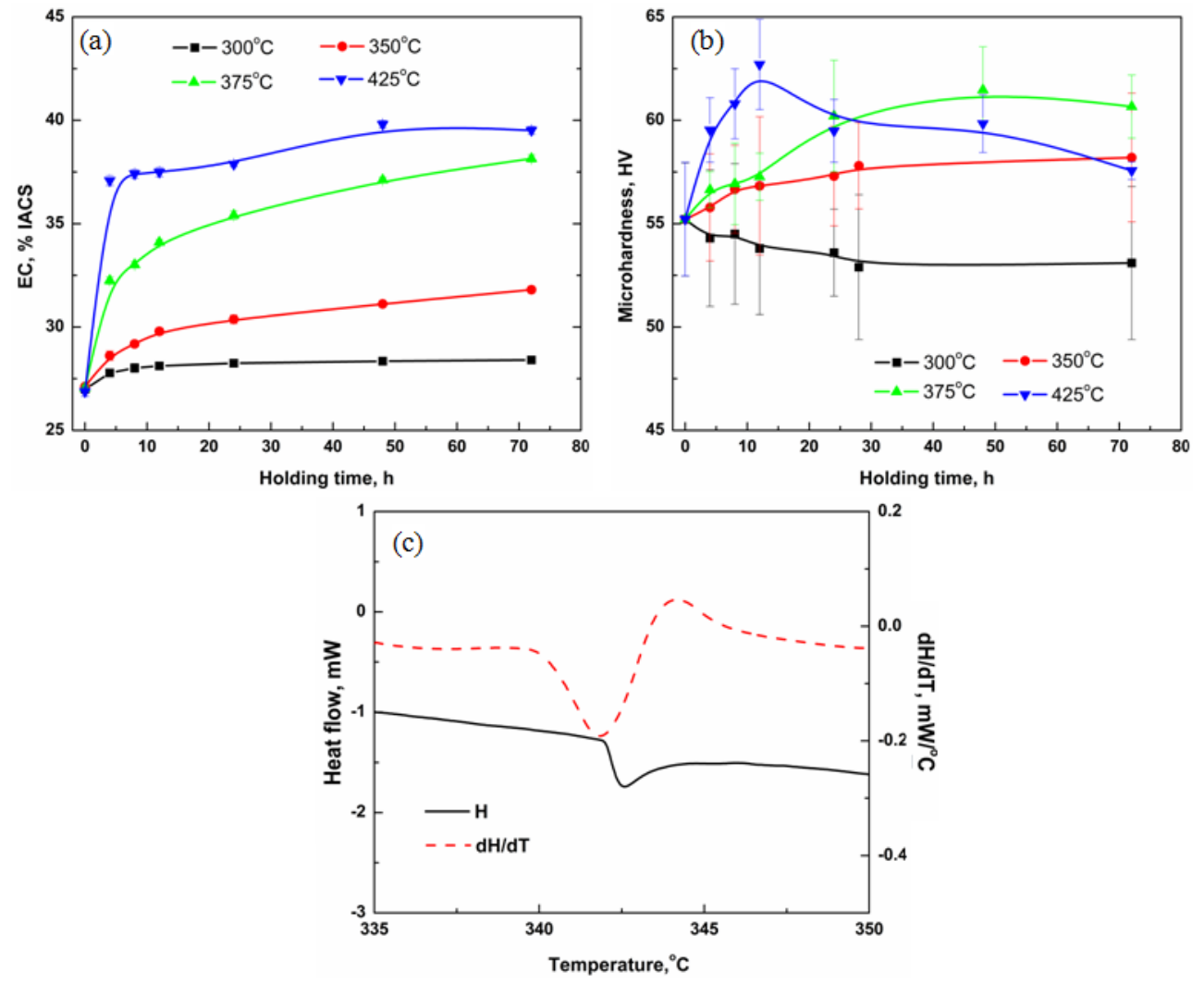

Fig. 6 Evolution of EC(a), and microhardness (b) during precipitation treatment and the precipitation temperature of dispersoids during DSC heating (c)

As shown in Fig. 6a, EC increases quickly in the beginning of holding and gradually increases to a peak; however, the maximum value and the time taken to reach it vary with the holding temperature. It can be observed that the highest $\mathrm{EC}$ reached in 72 hours increased from $29.2 \% \mathrm{IACS}$ at $300^{\circ} \mathrm{C}$ to 32.2 at $350^{\circ} \mathrm{C}, 38.6$ at $375^{\circ} \mathrm{C}$ and 40.2 at $425^{\circ} \mathrm{C}$. It seemed that more than 72 hours were required to reach the peak when the material was treated at $350^{\circ} \mathrm{C}$ and $375^{\circ} \mathrm{C}$ but less than 12 hours were required at $425^{\circ} \mathrm{C}$.

EC measurements were used to determine the amount of solute in solid solution; their relationship can be expressed as [3, 11, 29]:

$1 / \mathrm{EC}=0.0267+0.032 \mathrm{Fe}_{s s} \%+0.033 \mathrm{Mn}_{s s} \%+0.0068 \mathrm{Si}_{s s} \%+0.003 \mathrm{Mg}_{s s} \%+0.0021$ particle $\%$

Where, $\mathrm{Fe}_{s s} \%, \mathrm{Mn}_{s s} \%, \mathrm{Si}_{s s} \%$ and $\mathrm{Mg}_{s s} \%$ and particle\% are weight percentage. As shown in Eq. (2), $\mathrm{Si}_{s s}, \mathrm{Mg}_{s s}$ and particle percentages had much less effect on EC than $\mathrm{Mn}_{s s}$ and $\mathrm{Fe}_{s s}$, and most of $\mathrm{Fe}$ was in the form of intermetallics during solidification, such as $\mathrm{Al}_{6}(\mathrm{MnFe})$ and $\alpha-\mathrm{Al}(\mathrm{MnFe}) \mathrm{Si}$. Therefore, the changes of EC during precipitation treatment primarily depended on the concentration of $\mathrm{Mn}$ in solid solution. 
During precipitation treatment, the instant decomposition of the supersaturated solid solution leads to an increase in EC. However, the diffusion rate of Mn rapidly increases with temperature [17, 30]. Hence, EC increases with increasing temperature when treated for the same duration, and the time to reach the peak of EC decreases with increasing temperature (Fig. 6a). Finally, full decomposition of the supersaturated solid solution results in a stable EC as time proceeds.

Fig. $6 \mathrm{~b}$ shows the evolution of microhardness during holding, which is reflected in the effect of dispersoids precipitation on mechanical properties. When treated at $300^{\circ} \mathrm{C}$ with a prolonged soak time, a minor decrease in microhardness was observed, while an increasing trend was observed at 350 and $375^{\circ} \mathrm{C}$. At high temperature $\left(425^{\circ} \mathrm{C}\right)$, microhardness rapidly increased to its maximum after 12 hours and then decreased with increasing soak time.

The evolution of microhardness can be attributed to the precipitation and coarsening of $\alpha-\mathrm{Al}(\mathrm{MnFe}) \mathrm{Si}$ dispersoids during precipitation treatment. Fig. 6c shows a DSC curve revealing that the onset precipitation temperature of $\alpha-\mathrm{Al}(\mathrm{MnFe}) \mathrm{Si}$ dispersoids is near $342^{\circ} \mathrm{C}$. Therefore, it is difficult for dispersoids to precipitate at $300^{\circ} \mathrm{C}$. As shown in Fig. 7a, few fine dispersoids are found when the alloy was treated at $300^{\circ} \mathrm{C}$ for $48 \mathrm{~h}$. Table 3 summarizes the average equivalent diameter and volume fraction of dispersoids when treated for 48 hours at different temperatures. It can be found that the size of dispersoids after treatment at $300^{\circ} \mathrm{C}$ for $48 \mathrm{~h}$ is only $12 \mathrm{~nm}$, but the volume fraction is very low (0.006 vol.\%) due to the low precipitation temperature. Hence, the contribution of dispersoids to the microhardness is nearly negligible. On the other hand, the decreased concentration of $\mathrm{Mn}$ in solid solution indicated by the increasing EC in Fig. 6a weakens the solution strengthening effect of $\mathrm{Mn}$. Therefore, the microhardness gradually decreased with prolonged soak time at $300^{\circ} \mathrm{C}$. 


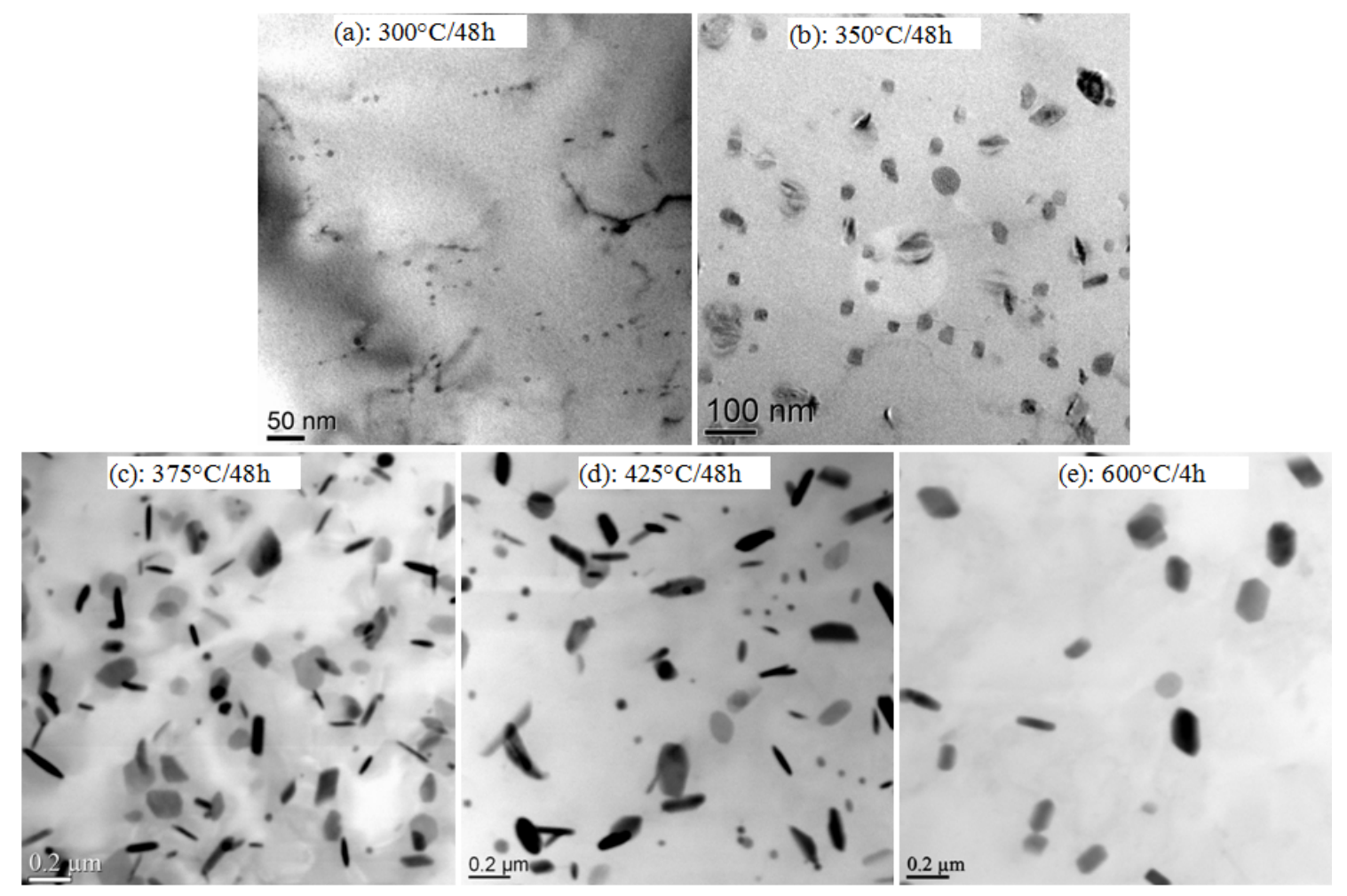

Fig. 7 Distribution of dispersoids at different conditions

Table 3 Characteristic of dispersoids and PFZ during precipitation treatment

$$
\text { Dispersoids }
$$

PFZ

Condition

Average equivalent Volume fraction, diameter, $\mathrm{nm}$ vol. \%

Volume fraction, vol. $\%$

\begin{tabular}{cccc}
\hline $300^{\circ} \mathrm{C} / 48 \mathrm{~h}$ & $11 \pm 3$ & $0.006 \pm 0.002$ & -- \\
$350^{\circ} \mathrm{C} / 48 \mathrm{~h}$ & $46 \pm 9$ & $0.78 \pm 0.12$ & $39 \pm 6$ \\
$375^{\circ} \mathrm{C} / 48 \mathrm{~h}$ & $61 \pm 11$ & $2.95 \pm 0.68$ & $28 \pm 3$ \\
$425^{\circ} \mathrm{C} / 48 \mathrm{~h}$ & $78 \pm 18$ & $1.94 \pm 0.43$ & $35 \pm 7$ \\
$600^{\circ} \mathrm{C} / 4 \mathrm{~h}$ & $135 \pm 16$ & $0.65 \pm 0.11$ & $41 \pm 8$ \\
\hline
\end{tabular}

When the alloy was treated at 350 and $375^{\circ} \mathrm{C}$, which is near the precipitation temperature of the dispersoids, continuous precipitation of fine dispersoids was dominant, and no significant coarsening was observed. As shown in Fig. 7, fine dispersoids were observed to be uniformly distributed in the matrix when treated at $350^{\circ} \mathrm{C}$ for $48 \mathrm{~h}$ (Fig. $7 \mathrm{~b}$ ) and at $375^{\circ} \mathrm{C}$ for $48 \mathrm{~h}$ (Fig. 7c). As shown in Table 3, the average size of the dispersoids after $350^{\circ} \mathrm{C}$ for $48 \mathrm{~h}$ is smaller $(46 \mathrm{~nm})$ than that after $375^{\circ} \mathrm{C}$ for $48 \mathrm{~h}(61 \mathrm{~nm})$, but the 
volume fraction after $375^{\circ} \mathrm{C}$ for $48 \mathrm{~h}$ was much higher ( 2.95 vol. \%) than that after $350^{\circ} \mathrm{C}$ for $48 \mathrm{~h}(0.78 \mathrm{vol} . \%)$, explaining the higher microhardness observed at $375^{\circ} \mathrm{C}$. Li et al. [5] reported that the volume fraction in AA 3003 alloy when treated at $375^{\circ} \mathrm{C}$ for $24 \mathrm{~h}$ was 0.77 vol. \%, which is much lower than that in the experimental 3004 alloy. One likely reason for this discrepancy is the high content of $\mathrm{Mg}(1.1 \mathrm{wt}$ \%) in the experimental 3004 alloy, which would promote the formation of $\mathrm{Mg}_{2} \mathrm{Si}$, which is reported to be the potential nuclei of $\alpha-\mathrm{Al}(\mathrm{MnFe}) \mathrm{Si}$ dispersoids [31]. With increasing precipitation temperature $\left(425^{\circ} \mathrm{C}\right)$ in this study, which is much higher than the precipitation temperature of $\alpha-\mathrm{Al}(\mathrm{MnFe}) \mathrm{Si}$ dispersoids, the precipitation of dispersoids is found to be much faster and then begin to coarsen with increasing soak time. Therefore, this effect results in a rapid increase of microhardness until the peak value is reached (approximately 12 hours). After the peak, dispersoids grow and coarsen, and the microhardness begins to decrease with the increase of soak time. As shown in Fig. $7 \mathrm{~d}$ and Table 3, the average size of the dispersoids reached $78 \mathrm{~nm}$ with a decreased volume fraction of $1.94 \mathrm{vol} . \%$ after $48 \mathrm{~h}$ at $425^{\circ} \mathrm{C}$. In addition, the formation of dispersoids after traditional homogenization treatment $\left(600^{\circ} \mathrm{C}\right.$ for 4 hours) is also shown in Fig. $7 \mathrm{e}$ and Table 3.

In addition to the size and volume fraction of dispersoids, another factor influencing mechanical properties during the precipitation treatment is the evolution of PFZ. It was reported that the volume fraction of PFZ first deceased then increased with increasing heat treatment temperature [10]. In present work, the volume fraction of PFZ also has been measured and summarized in Table 3. As shown in Table 3, the volume fraction of PFZ first decreased from 39 vol. $\%$ at $350^{\circ} \mathrm{C}$ after $48 \mathrm{~h}$ to 28 vol. $\%$ at $375^{\circ} \mathrm{C}$ after $48 \mathrm{~h}$. The decrease of PFZ also contributed to the increase of microhardness from $350^{\circ} \mathrm{C}$ after $48 \mathrm{~h}$ to $375^{\circ} \mathrm{C}$ after $48 \mathrm{~h}$ (Fig. 6). When treated at $425^{\circ} \mathrm{C}$ for $48 \mathrm{~h}$, the volume fraction of PFZ increased again from 28 vol. $\%$ at $375^{\circ} \mathrm{C}$ after $48 \mathrm{~h}$ to 35 vol. \%, which can be attributed to the coarsening of dispersoids and dissolution of dispersoids into the intermetallic particles in the interdendrite regions where the large intermetallic particles are located. Therefore, the increasing PFZ area also reduced the microhardness.

To evaluate the YS during the precipitation treatment, five conditions $\left(300^{\circ} \mathrm{C}\right.$ for $48 \mathrm{~h}, 350^{\circ} \mathrm{C}$ for $48 \mathrm{~h}, 375^{\circ} \mathrm{C}$ for $24 \mathrm{~h}, 375^{\circ} \mathrm{C}$ for $48 \mathrm{~h}$ and $425^{\circ} \mathrm{C}$ for $48 \mathrm{~h}$ ) were selected. In addition, traditional homogenization treated 3004 alloy at $600^{\circ} \mathrm{C}$ for $4 \mathrm{~h}$ was applied to compare with different precipitation treatment conditions in this study. For example, the typical true stress-strain curves from compression test at $300^{\circ} \mathrm{C}$, treated at $375^{\circ} \mathrm{C}$ for $48 \mathrm{~h}$, at $425^{\circ} \mathrm{C}$ for $48 \mathrm{~h}$ and at $600^{\circ} \mathrm{C}$ for $4 \mathrm{~h}$ are shown in Fig. 8a. Compared with the ashomogenized alloy, the flow stress is much higher in both precipitation treated conditions. As shown in Fig. 8a, the flow stress increased from $68 \mathrm{MPa}$ at the as-homogenized condition to $77 \mathrm{MPa}$ at $425^{\circ} \mathrm{C}$ for $48 \mathrm{~h}$ and further to $88 \mathrm{MPa}$ at $375^{\circ} \mathrm{C}$ for $48 \mathrm{~h}$. Fig. $8 \mathrm{~b}$ presents the evolution of YS during the precipitation treatments. Similar to the flow stress shown in Fig. 8a, YS after precipitation treatments are all higher than the 
as-homogenized material at both $\mathrm{RT}$ and $300^{\circ} \mathrm{C}$, indicating the remarkable strengthening effect. However, YS varied with precipitation treatment applied. As shown in Fig. 8b, YS gradually increased from $300^{\circ} \mathrm{C}$ for $48 \mathrm{~h}$ to a peak value at $375^{\circ} \mathrm{C}$ after $48 \mathrm{~h}$ then began to decrease at $425^{\circ} \mathrm{C}$ after $48 \mathrm{~h}$. For instance, the YS at RT and $300{ }^{\circ} \mathrm{C}$ increased from 93 and $63 \mathrm{MPa}$ at $300^{\circ} \mathrm{C}$ for $48 \mathrm{~h}$ to 104 and $78 \mathrm{MPa}$ at $375^{\circ} \mathrm{C}$ for $48 \mathrm{~h}$ and then reduced to 92 and $65 \mathrm{MPa}$ at $425^{\circ} \mathrm{C}$ after $48 \mathrm{~h}$, respectively. The YS at $300^{\circ} \mathrm{C}$ with proper precipitation treatment, such as $375^{\circ} \mathrm{C}$ for $48 \mathrm{~h}$, can reach $78 \mathrm{MPa}$, which is a $40 \%$ improvement compared with the as-homogenized material (56 MPa), indicating significant potential of the alloy for high temperature applications.
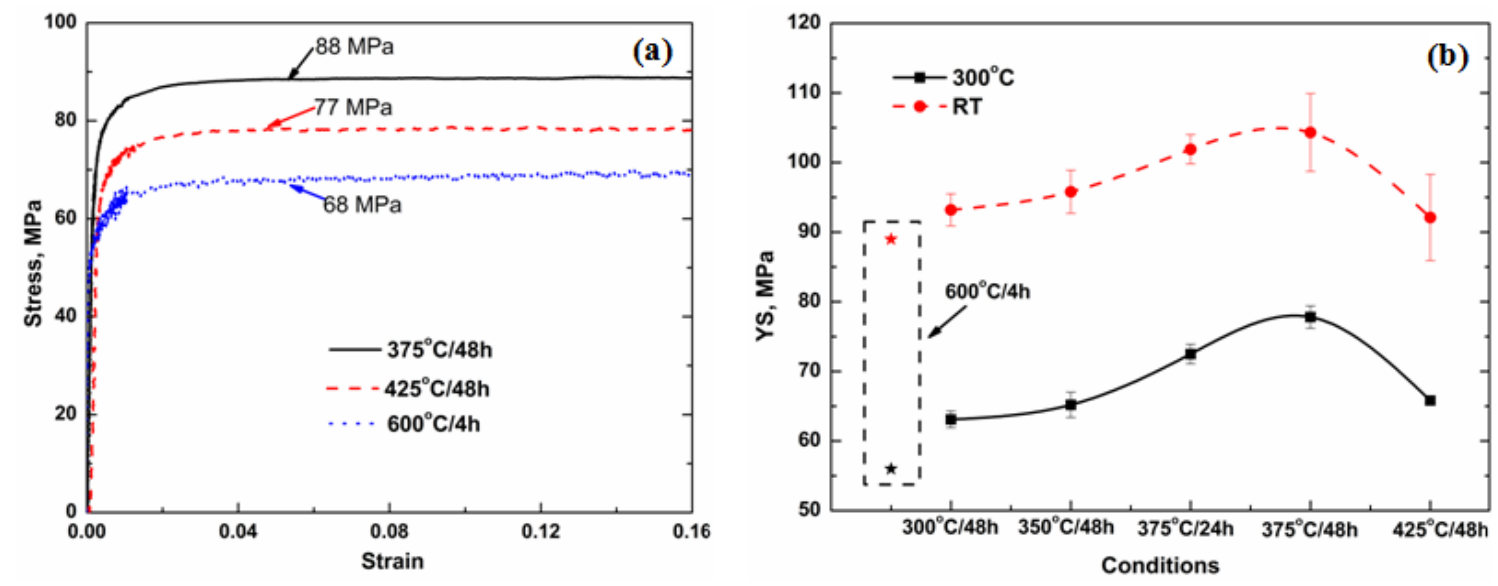

Fig. 8 Typical true stress-strain curves (a) and YS at both RT and $300^{\circ} \mathrm{C}$ at different treatment conditions (b)

For the evolution of mechanical properties during precipitation treatment, multiple mechanisms can be involved, such as changes in grain size, solid solution and the precipitation of $\alpha-\mathrm{Al}(\mathrm{MnFe}) \mathrm{Si}$ dispersoids. In this study, the EBSD technique was used to determine the grain structure and measure grain size. For example, the grain structures of the material after treatment at $300^{\circ} \mathrm{C}$ for $48 \mathrm{~h}$ and $375^{\circ} \mathrm{C}$ for $48 \mathrm{~h}$ are shown in Fig. 9. The different colors represent aluminum grains with different orientations. It can be found that the grain was coarse, and no major changes were observed in the average grain size during the precipitation treatment. Then, the increment of YS from the change of grain size could be negligible based on the Hall-Petch equation [19, 32]. Therefore, the evolution of YS could be significantly attributed to the synthetic effect of solid solution and dispersion strengthening.

According to the Orowan mechanism [3, 10, 11], the weak contribution of dispersion to mechanical properties at $600^{\circ} \mathrm{C}$ after $4 \mathrm{~h}$ and $300^{\circ} \mathrm{C}$ after $48 \mathrm{~h}$ can be attributed to either too fine $\left(300^{\circ} \mathrm{C}\right.$ after $\left.48 \mathrm{~h}\right)$ or too coarse $\left(600^{\circ} \mathrm{C}\right.$ after $\left.4 \mathrm{~h}\right)$ dispersoids and a low volume fraction of dispersoids. However, higher $\mathrm{EC}$ at $600^{\circ} \mathrm{C}$ after $4 \mathrm{~h}$ (35.5\%IACS) indicated a lower Mn concentration in solid solution than at $300^{\circ} \mathrm{C}$ for $48 \mathrm{~h}$; hence, the lower $\mathrm{YS}$ at $600^{\circ} \mathrm{C}$ after $4 \mathrm{~h}$ was likely caused by a decrease in $\mathrm{Mn}$ 
concentration from the decomposition of the supersaturated solid solution [33]. Conversely, the level of solute concentration of $\mathrm{Mn}$ is similar for $375^{\circ} \mathrm{C}$ after $48 \mathrm{~h}$ and $600^{\circ} \mathrm{C}$ after $4 \mathrm{~h}$ due to similar ECs, then the much higher $\mathrm{YS}$ at $375^{\circ} \mathrm{C}$ after $48 \mathrm{~h}$ could be primarily contributing to the precipitation of fine dispersoids with a considerable volume fraction (Fig. 7), indicating the significant strengthening effect of dispersoids at both RT and $300^{\circ} \mathrm{C}$. The increased YS from the dispersoids is always found to be higher than the decreased YS from the reducing concentration of Mn, indicated by increasing YS from $300^{\circ} \mathrm{C}$ after $48 \mathrm{~h}$ to $375^{\circ} \mathrm{C}$ after $48 \mathrm{~h}$. This provides the possibility that YS could be further improved by controlling the size, volume fraction and distribution of dispersoids during heat treatment.

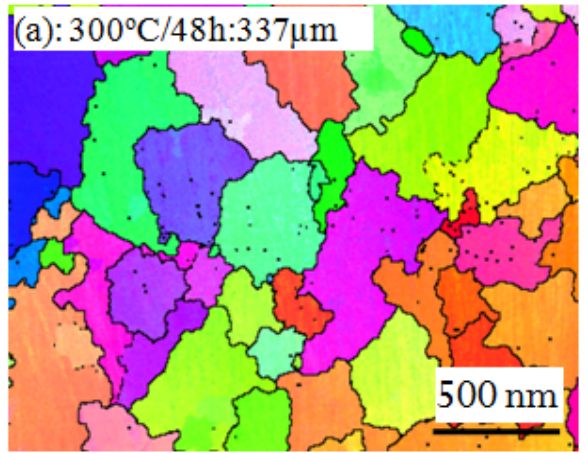

(c): $375^{\circ} \mathrm{C} / 48 \mathrm{~h}+300^{\circ} \mathrm{C} / 1000 \mathrm{~h}: 387 \mu \mathrm{m}$

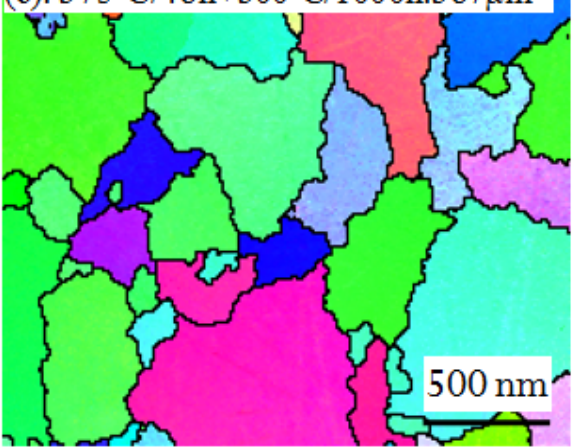

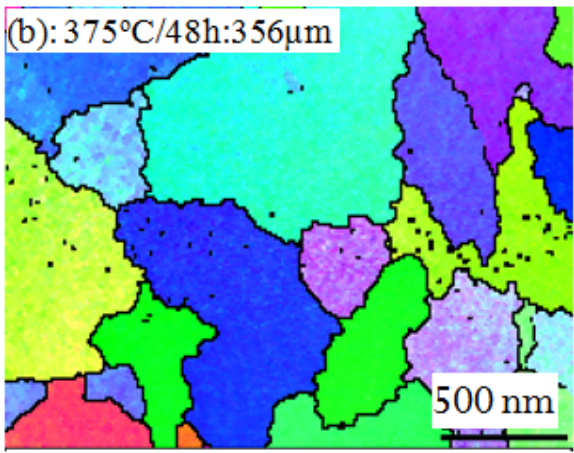

(d) Inversed pole figure (IPF)

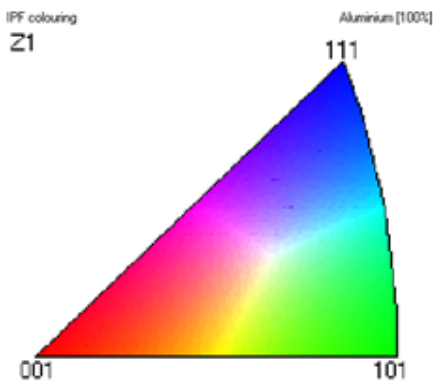

Fig. 9 EBSD micrographs that show grain size under various conditions

\subsection{Long-term thermal stability}

After peak precipitation treatment $\left(375^{\circ} \mathrm{C} / 48 \mathrm{~h}\right)$ to generate maximum strength (Figs. 6 and 8), a long-term thermal holding at $300^{\circ} \mathrm{C}$ for up to 1000 hours was performed to assess the thermal stability of the mechanical properties. Fig. 10 displays the plots of EC, microhardness and YS at both RT and $300^{\circ} \mathrm{C}$ during thermal holding.

As shown in Fig. 10a, the EC remains stable and marginally increases from $38 \%$ to $38.5 \%$ IACS after $1000 \mathrm{~h}$ of holding due to the complete decomposition of the supersaturated solid solution. The microhardness shows a minor decrease from 61.3 to 60.7 HV after 1000h while the YS shows a stable tendency during the entire holding 
process (Fig. 10b). It can be found that the YS remains at 104-105 MPa at RT and 77-78 $\mathrm{MPa}$ at $300^{\circ} \mathrm{C}$ after the $1000 \mathrm{~h}$ holding, indicating the excellent thermal stability of the experimental alloy at elevated temperature.
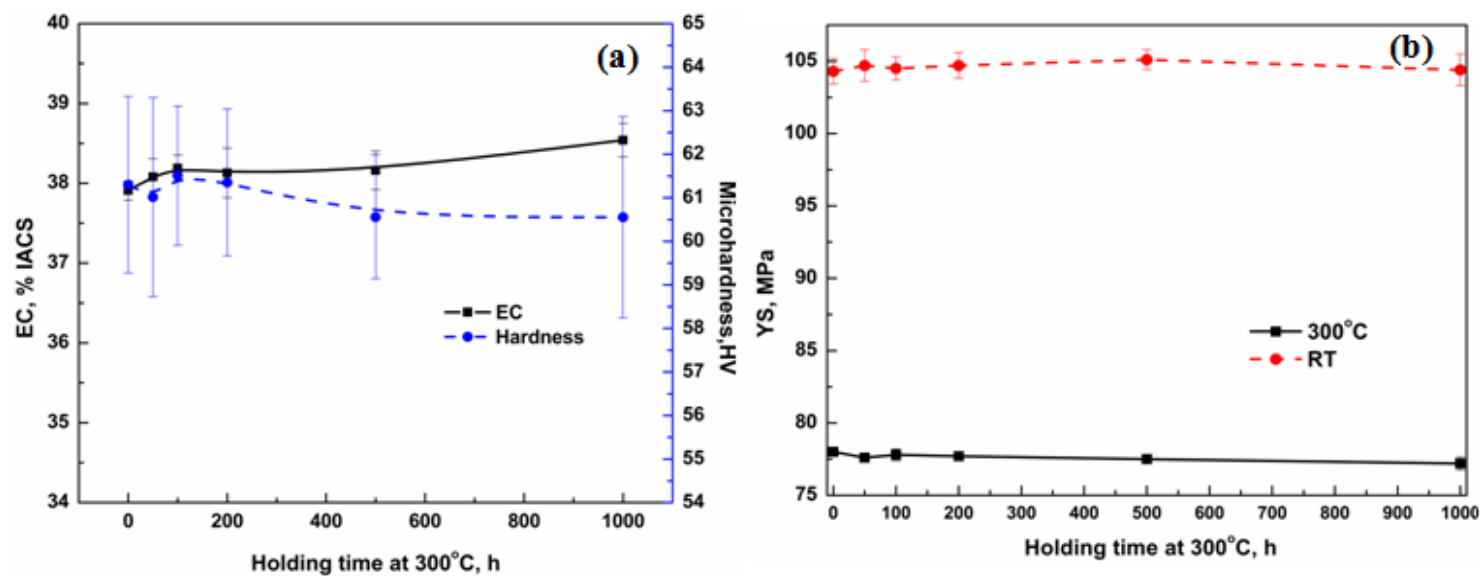

Fig. 10 Evolution of EC and hardness (a) and YS (b) during a long thermal holding

During thermal holding, grain growth was not observed. As shown in Fig. 9, the grain size only marginally changed from 356 to $387 \mu \mathrm{m}$ after $1000 \mathrm{~h}$, which were both quite coarse. TEM results in Fig. 11 indicate few changes in the size and distribution of dispersoids even after $1000 \mathrm{~h}$ holding at $300^{\circ} \mathrm{C}$. Image analysis shows that the size and volume fraction of dispersoids were $61 \mathrm{~nm}$ and $2.95 \mathrm{vol} . \%$ at initially and marginally changed to $64 \mathrm{~nm}$ and $2.87 \mathrm{vol} . \%$ after $1000 \mathrm{~h}$, respectively, confirming the thermal stability of $\alpha-\mathrm{Al}(\mathrm{MnFe}) \mathrm{Si}$ dispersoids, which results in stable mechanical properties of the experimental alloy at elevated temperature. It is expected that high YS will be kept for longer durations, such as above 2000 hours, due to the lower coarsening rate of $\alpha-\mathrm{Al}(\mathrm{MnFe}) \mathrm{Si}$ dispersoids.
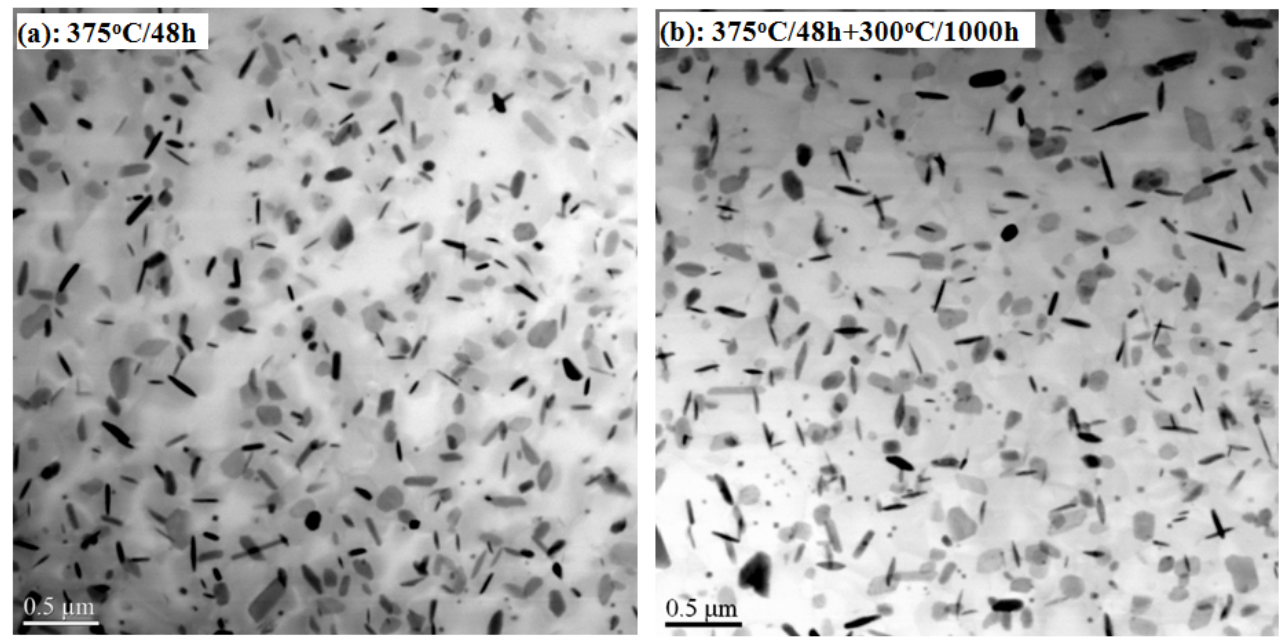

Fig. 11 STEM images showing the evolution of dispersoids during thermal holding 
Moreover, the creep resistance of the experimental alloy at $300^{\circ} \mathrm{C}$ was also preliminary investigated. As shown in Fig. 12a, the homo-treated sample already reached the measurement limitation of the creep machine ( 0.225 strain of creep deformation) after running just for 72 hours, showing very low creep resistance. Conversely, creep resistance was found to be much higher for the samples treated at $375^{\circ} \mathrm{C}$ for $48 \mathrm{~h}$ and $375^{\circ} \mathrm{C}$ for $48 \mathrm{~h}+300^{\circ} \mathrm{C}$ for $1000 \mathrm{~h}$, in which the total strain of both samples was only 0.01 after 72 hours (Fig. 12b), which was less than $5 \%$ of the creep deformation of the homotreated sample. Additionally, after the long thermal holding $(1000 \mathrm{~h})$, the creep resistance of 3004 alloy was only slightly lower than the sample without holding (Fig. 12b).The calculated creep rate of the homo-treated sample was $1.4 \times 10^{-6} \mathrm{~s}^{-1}$. It was $3.1 \times 10^{-8} \mathrm{~s}^{-1}$ without holding and $3.6 \times 10^{-8} \mathrm{~s}^{-1}$ after a $1000 \mathrm{~h}$ holding after peak precipitation treatment $\left(375^{\circ} \mathrm{C}\right.$ for $\left.48 \mathrm{~h}\right)$, respectively, in which the creep rates were in the same order but are two orders of magnitude lower than the homo-treated condition.
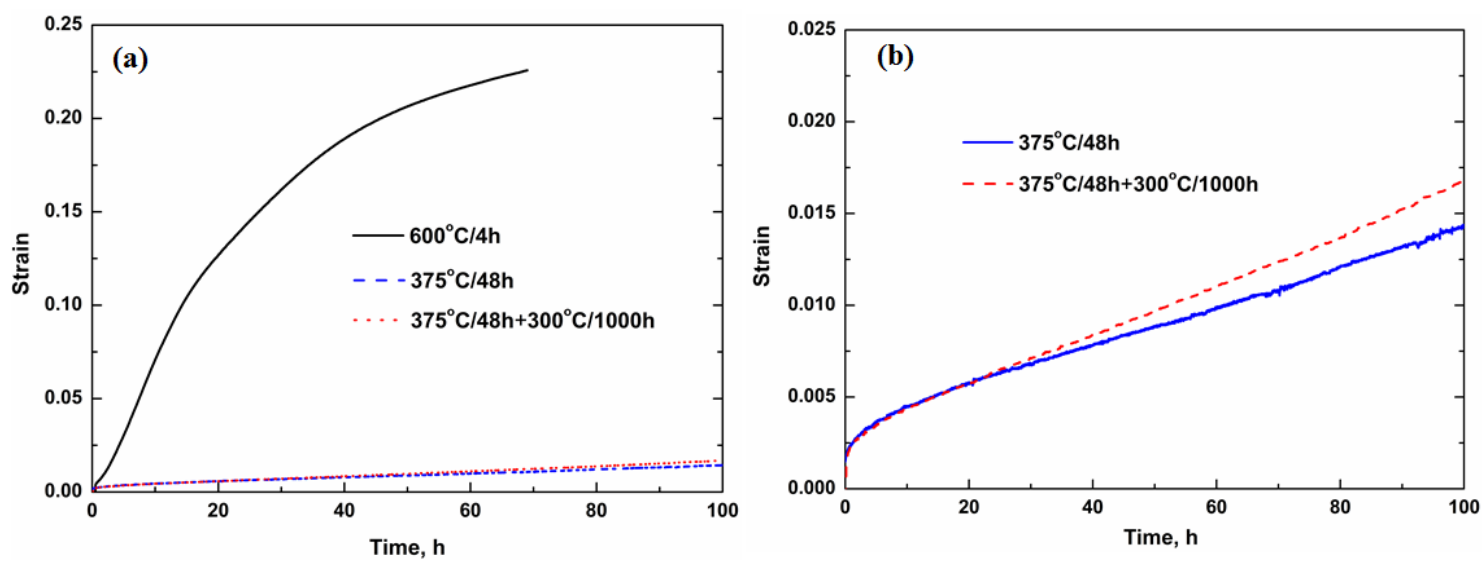

Fig. 12 Compression creep curves at different conditions at various strain range:

(a): $0-0.25$ and (b) $0-0.025$

Due to the similar level of Mn solution concentrations for these three conditions, it is evident that dispersoids play a significant role in creep resistance. According to the creep condition applied $\left(45 \mathrm{MPa}\right.$ at $300^{\circ} \mathrm{C}$ ), the creep mechanism is primarily controlled by the glide and climb of dislocations during creep [34]. As shown in Figs. 7 and 11, the volume fraction of dispersoids at $375^{\circ} \mathrm{C}$ after $48 \mathrm{~h}$ and $375^{\circ} \mathrm{C}$ after $48 \mathrm{~h}+300^{\circ} \mathrm{C}$ for $1000 \mathrm{~h}$ was much higher than $600^{\circ} \mathrm{C}$ for $4 \mathrm{~h}$, and the size of dispersoids was much finer; hence, dislocations were effectively pinned by the dispersoids, leading to a much higher creep resistance compared with the homo-treated sample. There were little changes in the size and volume fraction of dispersoids after a long thermal holding (Fig. 11), leading to a similar high creep resistance. Therefore, the high creep resistance observed after the proper precipitation treatment provided another advantage for the application of 3004 alloy at elevated temperature. 
3.4 Prospect of 3004 alloy in applications at elevated temperature

In order to fully develop the properties of 3004 alloy at elevated temperature, the compression YS as a function of temperature after the peak precipitation treatment $\left(375^{\circ} \mathrm{C}\right.$ for $\left.48 \mathrm{~h}\right)$ has been measured and shown in Fig. 13. Compared with the as-homogenized condition, it can be found that there is visible improvement in YS at low temperatures $\left(25-100^{\circ} \mathrm{C}\right)$, in which the YS increased from $89 \mathrm{MPa}$ as-homogenized to $103 \mathrm{MPa}$ after $375^{\circ} \mathrm{C}$ for 48 , showing a moderate strengthening effect of dispersoids on mechanical properties. However, the improvement of YS was more significant at elevated temperatures, such as $300-400^{\circ} \mathrm{C}$. As shown in Fig. 13, there was a $22 \mathrm{MPa}$ increase in YS at $300^{\circ} \mathrm{C}$ from as-homogenized (56 MPa) to after the peak precipitation treatment $(78 \mathrm{MPa})$, exhibiting a remarkable strengthening effect at elevated temperatures. Additionally, YS can reach as high as $55 \mathrm{MPa}$ even at $400^{\circ} \mathrm{C}$, providing a reliable and wide safety margin during exposure at higher service temperature.

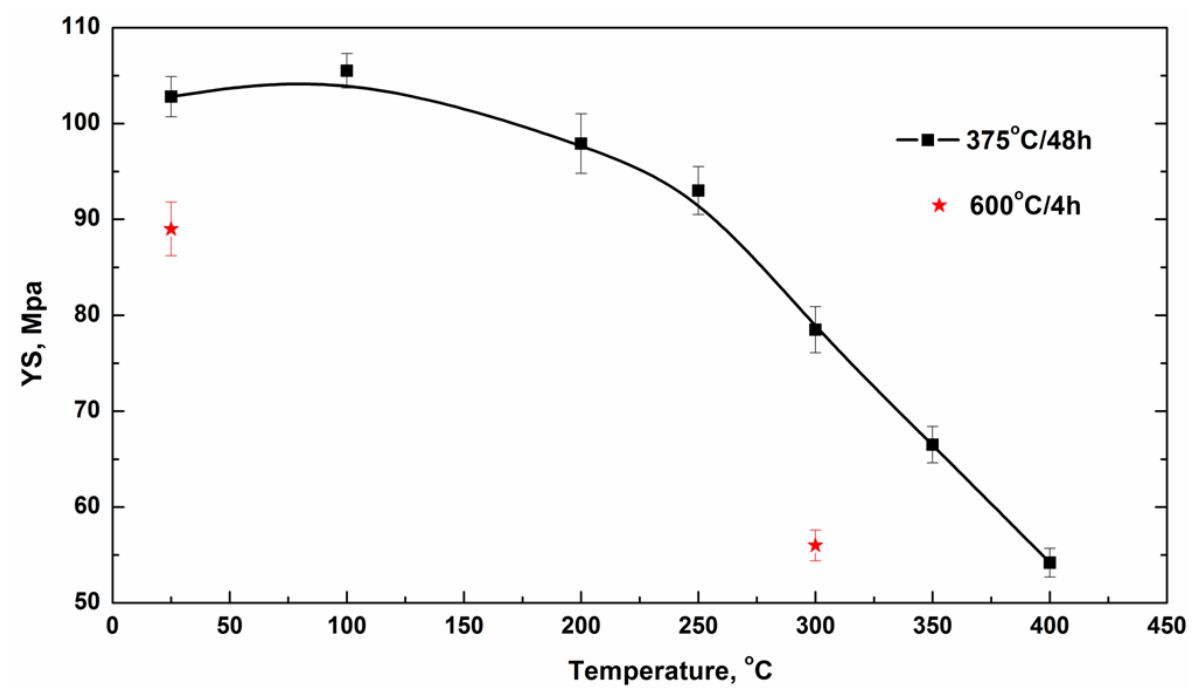

Fig. 13 YS of experimental 3004 alloy at various temperatures after $375^{\circ} \mathrm{C} / 48 \mathrm{~h}$

The significant strengthening effect of dispersoids at elevated temperature provide a promising advantage of the experimental alloy compared to traditional precipitation strengthening alloys, such as $2 \mathrm{xxx}, 6 \mathrm{xxx}$ and $7 \mathrm{xxx}$ alloys. The data in Table 4 shows that the mechanical properties of the experimental 3004 alloy are comparable to 2024-T6 (70 $\mathrm{MPa})$ but are much higher than 6061-T6 (55 MPa) and 7075-T6 (52 MPa) after $10 \mathrm{~h}$ holding. The long-term thermal stability of alloys is one of the most significant factors to be considered for applications at elevated temperature. Because of the rapid coarsening of precipitates in $2 \mathrm{xxx}, 6 \mathrm{xxx}$ and $7 \mathrm{xxx}$ alloys, those alloys exhibit a terrible deterioration of mechanical properties during prolonged exposure at elevated service temperatures. As shown in Table 4, the initial YS of 2024-T6 at $315^{\circ} \mathrm{C}$ was relatively high (95 MPa) but rapidly decreased to $70 \mathrm{MPa}$ after 10 hours and to $45 \mathrm{MPa}$ after 1000 hours. Similarly for 6061-T6, the YS decreased from $75 \mathrm{MPa}$ after 0.5 hours to $29 \mathrm{MPa}$ after 1000 hours at 
$315^{\circ} \mathrm{C}$, in which $61 \%$ of the YS had been lost after thermal holding. However, the YS remained stable for the experimental 3004 alloy during prolonged holding: $78 \mathrm{MPa}$ after the peak precipitation treatment without holding, and $77 \mathrm{MPa}$ after 1000 hours at $300^{\circ} \mathrm{C}$, indicating an excellent long-term thermal stability.

Table 4 YS of wrought aluminum alloys during the thermal holding

\begin{tabular}{cccccc}
\hline \multirow{2}{*}{ Source } & Alloy (Condition) & \multicolumn{5}{c}{ YS (MPa) after various thermal holding } \\
\cline { 3 - 6 } & $0.5 \mathrm{~h}$ & $10 \mathrm{~h}$ & $100 \mathrm{~h}$ & $1000 \mathrm{~h}$ \\
\hline $\begin{array}{c}\text { Literature [1] } \\
\text { (Holding and }\end{array}$ & $2024(\mathrm{~T} 6)$ & 95 & 70 & 55 & 45 \\
tested at 315 $\mathrm{C})$ & $6061(\mathrm{~T} 6)$ & 75 & 55 & 31 & 29 \\
\hline $\begin{array}{c}\text { Experimental } \\
(\text { Holding and } \\
\left.\text { tested at } 300^{\circ} \mathrm{C}\right)\end{array}$ & $3004\left(375^{\circ} \mathrm{C} / 48 \mathrm{~h}\right)$ & 78 & 77.9 & 77.6 & 77.2 \\
\hline
\end{tabular}

Recently, additions of transition and rare earth elements, such as individuals or combinations of $\mathrm{Sc}$ with $\mathrm{Zr}, \mathrm{Gd}, \mathrm{Er}$ and $\mathrm{Yb}$ to wrought aluminum alloy, particularly in $1 \mathrm{xxx}$ alloys, to improve the mechanical properties at elevated temperatures have been explored [35-38], in which reported that they can form coherent or semi-coherent $\mathrm{Al}_{3} \mathrm{M}$ dispersoids that are thermally stable up to $250-350^{\circ} \mathrm{C}$. However, the high cost of these elements (particularly $\mathrm{Sc}$ ) limits their wide application in aluminum alloys. On the other hand, common alloying elements such as $\mathrm{Mn}, \mathrm{Mg}$ and $\mathrm{Si}$ in 3xxx alloys are significantly more economic compared with Sc and other transition and rare earth elements. Additionally, 3xxx alloys can maintain their ability to be manufactured and processed with conventional ingot metallurgical techniques and become more competitive in largescale industrial production. Furthermore, the density of aluminum alloy is much lower than the other materials traditional used at high temperature, such as Ti alloys and Nibased alloys [39, 40]. Therefore, superior mechanical properties at elevated temperature after the proper precipitation treatment combined with long-term thermal stability, high creep resistance and a considerably lower manufacture cost provide a promising prospect of 3004 alloy for weight-sensitive applications at elevated temperature.

\section{Conclusions}

(1) The as-cast 3004 alloy consists of a dominant $\mathrm{Al}_{6}(\mathrm{MnFe})$ intermetallic phase with two minor phases of $\mathrm{Mg}_{2} \mathrm{Si}$ and $\alpha-\mathrm{Al}(\mathrm{MnFe}) \mathrm{Si}$ intermetallics. During precipitation treatment, the large $\mathrm{Al}_{6}(\mathrm{MnFe})$ phase begins to fragment and $\alpha-\mathrm{Al}(\mathrm{MnFe}) \mathrm{Si}$ dispersoids 
precipitate in dendrite grains, while PFZ mainly surrounds the secondary intermetallic particles.

(2) Significant dispersion strengthening can be achieved by the precipitation of $\alpha-\mathrm{Al}(\mathrm{MnFe}) \mathrm{Si}$ dispersoids during precipitation treatment. The peak compression YS can reach $78 \mathrm{MPa}$ due to a large volume fraction of fine and uniformly distributed dispersoids. The creep rates at $300^{\circ} \mathrm{C}$ after the peak precipitation treatment and after long-term thermal holding are two orders of magnitude lower than the as-homogenized condition, confirming the important role of dispersoids in material properties at elevated temperature.

(3) $\alpha-\mathrm{Al}(\mathrm{MnFe}) \mathrm{Si}$ dispersoids are approved to be thermally stable at $300^{\circ} \mathrm{C}$. The associated high mechanical properties and creep resistance can remain stable during longterm thermal holding.

(4) Compared with other common wrought alloys, superior mechanical properties at elevated temperature combined with the long-term thermal stability and excellent creep resistance provide a promising potential for applications of 3004 alloy at elevated temperature.

\section{Acknowledgments}

The authors would like to acknowledge the financial support of the Natural Sciences and Engineering Research Council of Canada (NSERC) and Rio Tinto Alcan through the NSERC Industry Research Chair in the Metallurgy of Aluminum Transformation at University of Quebec at Chicoutimi.

\section{References}

[1] Kaufman JG. Properties of aluminum alloys : tensile, creep, and fatigue data at high and low temperatures. Materials Park, Ohio; Washington, D.C.: ASM International ; Aluminum Association; (1999).

[2] Polmear IJ, Couper MJ. Design and development of an experimental wrought aluminum alloy for use at elevated temperatures. Metall Trans A, 19 (1988), pp. 10271035.

[3] Li YJ, Arnberg L. Quantitative study on the precipitation behavior of dispersoids in DC-cast AA3003 alloy during heating and homogenization. Acta Mater, 51 (2003), pp. 3415-3428.

[4] Huang H-W, Ou B-L. Evolution of precipitation during different homogenization treatments in a 3003 aluminum alloy. Mater Des, 30 (2009), pp. 2685-2692.

[5] Li YJ, Muggerud AMF, Olsen A, Furu T. Precipitation of partially coherent $\alpha$ $\mathrm{Al}(\mathrm{Mn}, \mathrm{Fe}) \mathrm{Si}$ dispersoids and their strengthening effect in AA 3003 alloy. Acta Mater, 60 (2012), pp. 1004-1014.

[6] Farkoosh AR, Grant Chen X, Pekguleryuz M. Dispersoid strengthening of a high temperature Al-Si-Cu-Mg alloy via Mo addition. Mater Sci Eng, A, 620 (2015), pp. 181-189. 
[7] Farkoosh AR, Grant Chen X, Pekguleryuz M. Interaction between molybdenum and manganese to form effective dispersoids in an $\mathrm{Al}-\mathrm{Si}-\mathrm{Cu}-\mathrm{Mg}$ alloy and their influence on creep resistance. Mater Sci Eng, A, 627 (2015), pp. 127-138.

[8] Zhang Y, Yang L, Dai J, Ge J, Guo G, Liu Z. Effect of Ca and Sr on the compressive creep behavior of Mg-4Al-RE based magnesium alloys. Mater Des, 63 (2014), pp. 439445.

[9] Kamat R. AA3104 can-body stock ingot: Characterization and homogenization. JOM, 48 (1996), pp. 34-38.

[10] Li Y, Arnberg L. Precipitation of Dispersoids in DC-Cast AA31O3 Alloy during Heat Treatment. Essential Readings in Light Metals: John Wiley and Sons; 2013. pp. 1021-1027.

[11] Muggerud AMF, Mørtsell EA, Li Y, Holmestad R. Dispersoid strengthening in AA3xxx alloys with varying $\mathrm{Mn}$ and $\mathrm{Si}$ content during annealing at low temperatures. Mater Sci Eng, A, 567 (2013), pp. 21-28.

[12] Muggerud AMF, Li Y, Holmestad R. Composition and orientation relationships of constituent particles in 3xxx aluminum alloys. Philos Mag, 94 (2014), pp. 556-568.

[13] Muggerud AMF, Li YJ, Holmestad R. Orientation studies of á-Al(Fe,Mn)Si dispersoids in 3xxx Al alloys. 14th International Conference on Aluminium Alloys, ICAA 2014. Trondheim: Trans Tech Publications Ltd; 2014. pp. 39-44.

[14] Dehmas M, Aeby-Gautier E, Archambault P, Serrière M. Interaction between eutectic intermetallic particles and dispersoids in the 3003 aluminum alloy during homogenization treatments. Metall Mater Trans A, 44 (2013), pp. 1059-1073.

[15] Öz T, Karaköse E, Keskin M. Impact of beryllium additions on thermal and mechanical properties of conventionally solidified and melt-spun Al-4.5 wt.\% Mn-Xwt.\%Be (x=0,1,3,5) alloys. Mater Des, 50 (2013), pp. 399-412.

[16] Mahmudi R, Kabirian F, Nematollahi Z. Microstructural stability and hightemperature mechanical properties of AZ91 and AZ91+2RE magnesium alloys. Mater Des, 32 (2011), pp. 2583-2589.

[17] Knipling KE, Dunand DC, Seidman DN. Criteria for developing castable, creepresistant aluminum-based alloys - A review. Z METALLKD, 97 (2006), pp. 246-265.

[18] Miresmaeili SM, Nami B. Impression creep behavior of Al-1.9\% Ni-1.6\% Mn-1\% Mg alloy. Mater Des, 56 (2014), pp. 286-290.

[19] Lai J, Zhang Z, Chen XG. The thermal stability of mechanical properties of Al-B4C composites alloyed with $\mathrm{Sc}$ and $\mathrm{Zr}$ at elevated temperatures. Mater Sci Eng, A, 532 (2012), pp. 462-470.

[20] Li Y, Langdon TG. Creep behavior of an Al-6061 metal matrix composite reinforced with alumina particulates. Acta Mater, 45 (1997), pp. 4797-4806.

[21] Li Y, Langdon TG. Creep behavior of a reinforced Al-7005 alloy: Implications for the creep processes in metal matrix composites. Acta Mater, 46 (1998), pp. 1143-1155.

[22] Davis JR, Associates, International ASM, Handbook C. Aluminum and aluminum alloys. Materials Park, OH: ASM International; (1993).

[23] Weibel ER, Elias H, International Society for S. Quantitative methods in morphology. Quantitative Methoden in der Morphologie; proceedings. Berlin; New York: Springer-Verlag; (1967).

[24] Liu PX, Liu Y, Xu R. Microstructure quantitative analysis of directionally solidified Al-Ni-Y ternary eutectic alloy. Chin J Nonferrous Met, 24 (2014), pp. 2443-2451. 
[25] Es-Said OS, Zeihen A, Ruprich M, Quattrocchi J, Thomas M, Shin KH, et al. Effect of processing parameters on the earing and mechanical properties of strip cast type 3004 Al alloy. J Mater Eng Perform, 3 (1994), pp. 123-134.

[26] Li YJ, Arnberg L. Evolution of eutectic intermetallic particles in DC-cast AA3003 alloy during heating and homogenization. Mater Sci Eng, A, 347 (2003), pp. 130-135.

[27] Liu K, Cao X, Chen XG. Solidification of iron-rich intermetallic phases in Al4.5Cu-0.3Fe cast alloy. Metall Mater Trans A, 42 (2011), pp. 2004-2016.

[28] Liu K, Cao X, Chen XG. Formation and phase selection of iron-rich intermetallics in Al-4.6Cu-0.5Fe cast alloys. Metall Mater Trans A, 44 (2013), pp. 682-695.

[29] Zhao Q, Holmedal B, Li Y. Influence of dispersoids on microstructure evolution and work hardening of aluminium alloys during tension and cold rolling. Philos Mag, 93 (2013), pp. 2995-3011.

[30] Du Y, Chang YA, Huang B, Gong W, Jin Z, Xu H, et al. Diffusion coefficients of some solutes in fcc and liquid Al: Critical evaluation and correlation. Mater Sci Eng, A, 363 (2003), pp. 140-151.

[31] Lodgaard L, Ryum N. Precipitation of dispersoids containing Mn and/or Cr in AlMg-Si alloys. Mater Sci Eng, A, 283 (2000), pp. 144-152.

[32] Hansen N. The effect of grain size and strain on the tensile flow stress of aluminium at room temperature. Acta Metall, 25 (1977), pp. 863-869.

[33] Ryen $\varnothing$, Holmedal B, Nijs O, Nes E, Sjölander E, Ekström H-E. Strengthening mechanisms in solid solution aluminum alloys. Metall Mater Trans A, 37 (2006), pp. 1999-2006.

[34] Dieter GE. Mechanical metallurgy. New York: McGraw-Hill; (1976).

[35] Booth-Morrison C, Dunand DC, Seidman DN. Coarsening resistance at $400{ }^{\circ} \mathrm{C}$ of precipitation-strengthened Al-Zr-Sc-Er alloys. Acta Mater, 59 (2011), pp. 7029-7042.

[36] Knipling KE, Karnesky RA, Lee CP, Dunand DC, Seidman DN. Precipitation evolution in Al-0.1Sc, Al-0.1Zr and Al-0.1Sc-0.1Zr (at.\%) alloys during isochronal aging. Acta Mater, 58 (2010), pp. 5184-5195.

[37] Van Dalen ME, Dunand DC, Seidman DN. Nanoscale precipitation and mechanical properties of Al-0.06 at.\% Sc alloys microalloyed with Yb or Gd. J Mater Sci, 41 (2006), pp. 7814-7823.

[38] Peng G, Chen K, Fang H, Chen S. Effect of Cr and Yb additions on microstructure and properties of low copper Al-Zn-Mg-Cu-Zr alloy. Mater Des, 36 (2012), pp. 279-283. [39] Wang T, Wang C, Sun W, Qin X, Guo J, Zhou L. Microstructure evolution and mechanical properties of $\mathrm{GH} 984 \mathrm{G}$ alloy with different $\mathrm{Ti} / \mathrm{Al}$ ratios during long-term thermal exposure. Mater Des, 62 (2014), pp. 225-232.

[40] Chen XM, Lin YC, Chen MS, Li HB, Wen DX, Zhang JL, et al. Microstructural evolution of a nickel-based superalloy during hot deformation. Mater Des, 77 (2015), pp. 41-49. 